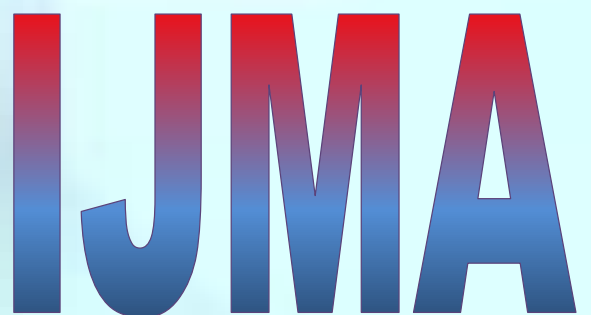

INTERNATIONAL

Journal of MEdical

\section{ARTS}

Volume 3, Issue 1 (Winter 2021)

http://ijma.journals.ekb.eg/

Print ISSN: 2636-4174

Online ISSN: 2682-3780

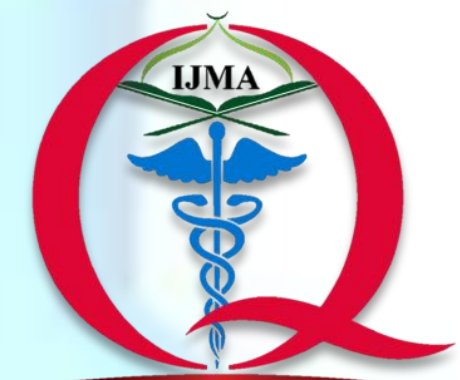

International Jounnal of Medical Arts

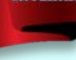



International Journal of Medical Arts 2021; 3 [1]: 967- 975.

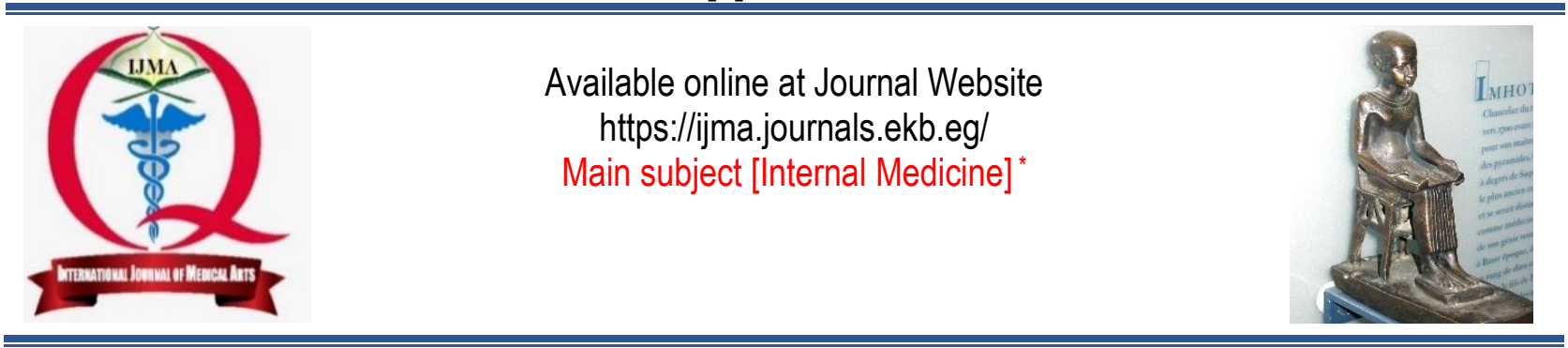

Original article

\title{
Relationship between Vitamin D Receptor Gene Polymorphism Fokl and Fetuin-A as Marker of Vascular Calcification in Egyptian Hemodialysis Patients
}

\author{
Fatma Ibrahim Mayah [1]; Hayam Hamza Mansour[1]; Ragaa Ramadan Mohamed[1]; Nadia Kamal Marey[1]; \\ Khaled Younis Mohammed[2]; Amr Mohamed Ibrahim[3]; Tarek Fakhr eldeen Osman[4] \\ Department of Internal Medicine, Faculty of Medicine for Girls, Al Azhar University, Egypt[1] \\ Department of Internal Medicine National Research Center, Egypt [2] \\ Department of Clinical Pathology National Research Center, Egypt ${ }^{[3]}$ \\ Department of Nephrology, National Institute of Urology and Nephrology, Egypt[4]
}

Corresponding author: Fatma Ibrahim Mayah

Email: fatmamayah343@yahoo.com

Received at: August 18, 2020; Revised at: October 20, 2020; Accepted at: October 29, 2020

DOI: 10.21608/ijma.2020.31335.1130

ABSTRACT
Background: Vascular calcification is a common complication in end-stage renal disease patients and the leading cause of morbidity and mortality.

Aim of the work: The current work aimed to evaluate the possible relationship between vitamin $D$ receptor gene polymorphism Fokl with fetuin-A and intact parathormone hormone in Egyptian hemodialysis patients.

Patient and Methods: This study is a cross-sectional study including 50 hemodialysis patients attending the hemodialysis unit in Al-Zahra University Hospital and 30 apparently healthy persons as a control group. For all studied subjects, a detailed history was taken, physical examination, carotid intima-media thickness by carotid duplex, echocardiography, Laboratory investigations included serum levels of calcium, phosphorus, iPTH, fetuin, and genotype frequency by PCR

Results: There was a highly significant increase in carotid intimal media thickness in the patient group Vs. control group \& a highly significant decrease in serum Fetuin-A in the patient's group Vs. control group. There was a significant difference in the genotype distribution of Fokl polymorphism among patients and control. There were significant negative relationships between FF genotype and iPTH and a highly significant negative correlation between serum fetuin-A and $\mathrm{PTH}$ in the patient group.

Conclusion: Vitamin D receptor gene Fokl polymorphism FF genotyping is more frequent in hemodialysis patients who have higher iPTH and lower fetuin-A levels, which could identify the high-risk group susceptible to vascular calcification in hemodialysis patients. Further studies are needed.

Keywords: Vascular Calcification; Vitamin-D Receptor Polymorphism; Fokl; Fetuin-A; Parathormone hormone.

This is an open-access article registered under the Creative Commons, ShareAlike 4.0 International license [CC BY-SA 4.0] [https://creativecommons.org/licenses/by-sa/4.0/legalcode.

Please cite this article: Mayah FI, Mansour HH, Mohamed RR, Marey NK, Mohammed KY, Ibrahim AM, Osman TF. Relationship between Vitamin-D Receptor Gene Polymorphism Fokl and Fetuin-A as Markers of Vascular Calcification in Egyptian Hemodialysis Patients IJMA 2021; 3[1]: 967- 975. DOI: 10.21608/IJMA.2020.31335.1130

* Main subject and any subcategories have been classified according to the research topic 


\section{INTRODUCTION}

Cardiovascular disease is the primary cause of morbidity and mortality in chronic kidney disease [CKD]. Some studies reported that about $40 \%$ of hemodialysis patients [HD] developed cardiovascular diseases [CVD][1]. Vascular calcification is a prominent feature of arterial disease in CKD and may impact cardiovascular mortality by modulating both arteriosclerosis [arterial stiffening] and atherosclerosis[2]. The nature of vascular calcification is progressive and is associated with arterial stiffness and increased mortality. Age, duration of dialysis, and diabetes mellitus are clear determinants of the severity of calcification; however, novel insights into the pathomechanisms of unwanted calcification processes have been gained more recently. Disturbances of mineral metabolism such as hyperphosphatemia and hypercalcemia appear to contribute to progressive calcification, not only by passive precipitation but by actively inducing changes in vascular smooth muscle cell behavior toward an osteoblast-like phenotype. Specific calcium-regulatory proteins may act locally or systemically as calcification inhibitors. Dysregulation of them, including fetuinA, matrix Gla protein, osteoprotegerin, and pyrophosphates, may also be pathophysiological relevant factors in the context of uremic extraosseous calcification [3].

Increased serum level of parathormone hormone $[\mathrm{PTH}]$ and hyperphosphatemia are risk factors for CVD and increased HD patients' mortality. Vitamin $D$ signals through its receptors [vitamin D receptors] [VDR], a specific zinc-finger nuclear receptor. Vitamin-D functions are characterized as genomic, mediated through the VDR transcriptional effects inside the cell nucleus, and non-genomic when the VDR induces rapid signaling [4]. Genetic-association studies have demonstrated that variations in VDR function induced by polymorphisms at the $3^{\prime}$ and $5^{\prime}$ regions of the VDR gene may have an effect on mortality risk in hemodialysis patients ${ }^{[5]}$.s The VDR is a member of the superfamily of nuclear hormone receptors. Its protein consists of 427 amino acids in humans, with a molecular mass of $\sim 48 \mathrm{kDa} a^{[6]}$. A polymorphism is a genetic variant that appears in at least $1 \%$ of the population. It can occur in the coding or non-coding region of the genome. The majority of polymorphisms are silent, meaning that they occur in the non-coding region[introns] and therefore do not alter the function or expression of a gene. If a gene polymorphism is located in the coding region of the genome[exons], it can alter the expression of the gene and create variation within a given population. Because of their abundance in the human genome and their high frequency in the human population, it has often been studied to explaining variation in the risk for common diseases ${ }^{[7]}$.

Several common genetic variants have been identified in the VDR gene, including the Fokl[' $f$ ], Bsml ['b'], Tru9l ['u'], EcoRV, Apal['a'], and Taql['t'] polymorphisms, identified by a biallelic variation in a restriction endonuclease site and their name based on the restriction endonuclease ${ }^{[8]}$. The discovery of genetic variants linked with diseases' susceptibility can be useful in preventive medicine. If a relationship with the disease emerges from association studies, this finding would strongly support the idea that the candidate gene is in some way involved in the disease [9].

\section{AIM OF THE WORK}

The current work aimed to evaluate the relationship between VDR gene Fokl polymorphism and both fetuin-A level and IPTH as the main factors involved in vascular calcification in hemodialysis patients.

\section{SUBJECT AND METHODS}

The current work was across sectional study including 50 patients with end-stage renal disease on regular $\mathrm{HD}$ for at least 6 months, 4 hours/session, 3 times per week. Cases were selected from those attending hemodialysis units in Al-Zahra University Hospital from October 2016 to May 2017. Oral consent was obtained from all of them, approval for the study approval was obtained from Al- Azhar University's ethics committee. They were 34 males [68\%] and 16 females [32\%], their age ranged from 28 to 77 years, thirty apparently healthy subjects were served as the control group, they were17 males [56.7 \%] and 13 females [43.3\%], their age ranged from 35 to 70 years. None of the patients had vitamin D therapy or therapy for high PTH. Ischemic heart diseases, liver cirrhosis, infection, and inflammatory bowel disease were excluded. 
All Patients and control groups were subjected to; careful history and full clinical examination. Echocardiography, Doppler study for carotid intima-media thickness [CIMT] Laboratory investigations showed that 2samples were taken from the patients. $5 \mathrm{ml}$ whole blood on EDTA for genotype frequency in which Genomic DNA was extracted from whole blood samples using the QlaAmp DNA Blood Midi Kit. Genotyping of the Fokl [rs2228570] polymorphism was performed using the polymerase chain reaction fragment length polymorphism [PCR-RFLP] analysis. The Fokl polymorphism was detected using forward primer 5-AGC TGG CCC TGG CAC TGA CTC TGC TCT-3 and reverse primer 5-ATG GAA ACA CCT TGC TTC TTC TCC-3, which amplify 265 base pair [bp] fragment containing Fokl site. PCR was performed for the Fokl polymorphism at the following condition:

After denaturation at $95{ }^{\circ} \mathrm{C}$ for $5 \mathrm{~min}, 35$ cycles were performed with denaturation for $45 \mathrm{~s}$ at $94{ }^{\circ} \mathrm{C}$, hybridization For $45 \mathrm{~s}$ at $60{ }^{\circ} \mathrm{C}$, and elongation for $45 \mathrm{~s}$ at $72{ }^{\circ} \mathrm{C}$; the last cycle was followed by an extension step of $10 \mathrm{~min}$ at $72^{\circ} \mathrm{C}$. PCR products were checked by electrophoresis on $2 \%$ agarose gel. The PCR products were digested with the respective restriction Enzymes according to the manufacturer's instructions as follows: at 37 ${ }^{\circ} \mathrm{C}$ for $5 \mathrm{~min}$ with Fokl Digested products separated in $3 \%$ agarose gels and visualized by ethidium bromide staining and genotype were determined according to the digestion pattern. Furthermore, Fokl polymorphism is confirmed by PCR repetition and PCR product commercial sequencing [genfanavaran]. Digested products for Fokl polymorphism contain 196 bp and 69 bp530 $\mathrm{bp}$ and $210 \mathrm{bp}$ fragments that indicated $\mathrm{f}$ allele and undigested alleles as $F$. And $5 \mathrm{ml}$ serum for fetuin $A$ and other tests which include fasting Blood sugar [FBS], blood urea, serum creatinine, Serum Calcium, Phosphorus, iPTH, Serum Albumin, total cholesterol and triglyceride. As regard to Fetuin $A$; Pre-dialysis blood sampling from a peripheral vein was performed after $12 \mathrm{~h}$ of overnight fasting. Subsequent serums were separated within $30 \mathrm{~min}$ and samples were kept frozen at $-70{ }^{\circ} \mathrm{C}$ until analysis was done. In the BioVendor Human Fetuin-A ELISA, Standards, Quality Controls and samples are incubated in microplate wells pre- coated with polyclonal anti-human Fetuin-A antibody. After 60 minutes' incubation and washing, polyclonal anti-human Fetuin-A antibody, conjugated with horseradish peroxidase [HRP] is added to the wells and incubated for 60 minutes with captured Fetuin A. Following another washing step, the remaining HRP conjugate is allowed to react with the substrate solution [TMB]. The reaction is stopped by the addition of an acidic solution

The absorbance of the resulting yellow product is measured spectrophotometrically at $450 \mathrm{~nm}$. The absorbance is proportional to the concentration of Fetuin-A. A standard curve is constructed by plotting absorbance values against concentrations of Standards, and concentrations of unknown samples are determined using this standard curve. Most microplate readers perform automatic calculations of analyte concentration. The standard curve is constructed by plotting the mean absorbance at $450 \mathrm{~nm}$ [Y] of standards against the log of the known concentration $[X]$ of standards, using the four-parameter algorithm, and results are reported as the concentration of FetuinA [ng/ml] in samples. The complete blood picture was determined on Coulter Counter T890 was used [Coulter Counter, Hardened, UK]. Determination of fasting blood sugar, kidney function tests, and lipid profile were done on Hitachi auto analyzer 736. Calcium and phosphorus were determined using standard laboratory techniques with commercial kits]. Serum Albumin was assayed by an enzymatic colorimetric method with an automated chemical analyzer. Serum iPTH was determined by enzyme-linked immunosorbent assay [ELISA] using the Immunodiagnostic system.

Statistical analysis: Statistical analysis was conducted, tabulated, and analyzed using Statistical Package for Social Science [SPSS] program, software version 20. All continuous variables were expressed as mean \pm standard deviation. The data were analyzed using the Student and chi-square test. Calculation of Spearman coefficient to determine the correlation between biochemical parameters. $P$ values less than 0.05 were considered significant, and more than 0.05 none significant. 


\section{RESULTS}

As regard age and sex, there was no significant difference between the studied groups. The causes of ESRD were: 31 patients [62\%] were hypertensive, 11 patients [22\%] with diabetic nephropathy, 4 patients [8\%] of unknown etiology, 1 patient [2\%] with polycystic disease, 1[2\%] amyloidosis,1 [2\%] lupus nephritis, and 1patient [2\%] with analgesic nephropathy [Table 1]. There was a highly significant increase in CIMT in the patients' group than in the control group [Figure 1]. Echocardiographic findings in the patient group were 23 patients [46\%] with the calcific aortic valve, 12 with the calcific mitral valve, and 3 [6\%] with both Calcific aortic and mitral valve, and 12 [24\%] with normal echocardiographic finding [Table 2]. There was a highly significant decrease in serum Fetuin-A in patient's group [36.5 \pm 8.05 ] $\mathrm{ng} / \mathrm{ml}$ in comparison to control group [82.5 \pm 9.12 ] $\mathrm{ng} / \mathrm{ml}[\mathrm{P}$-value < 0.001] [Figure 2]. There was a statistically significant negative correlation between serum fetuin $A$ and $\mathrm{PTTH}$ in the patient group $[r=-0.851 P=0.000$ ] [Figure 3]. There was no significant correlation between valvular calcification and fetuin-A in hemodialysis patients [Table 3]. There was a highly significant difference in the genotype distribution of Fokl polymorphism among patient and control groups $P$-value $\leq 0.001$. In patient group, the distribution frequencies of $\mathrm{FF}$, $\mathrm{Ff}$, and ff genotypes were 32 [64\%], 18 [36\%] and $0[0 \%]$ respectively, while in control group the distribution frequencies of $\mathrm{FF}, \mathrm{Ff}$, and ff Genotypes were 16 [53.3\%], $0[0 \%]$ and 14[46.7\%] respectively [Table 4]. There was a significant increase in IPTH in FF genotype than Ff genotype $p$ value $=0.014$, while there was no significant relation with other lab parameters [Figure 4]. There was no significant relation between fokl polymorphism genotype frequencies and fetuin-A in the patient group.

Table [1]: Baseline characteristics of studied groups

\begin{tabular}{|c|c|c|c|c|c|c|}
\hline & Patients group & Control group & \multirow[t]{2}{*}{ Test value } & \multirow[t]{2}{*}{ Pvalue } & \multirow[t]{2}{*}{ Sig. } \\
\hline & & No. $=50$ & No. $=30$ & & & \\
\hline \multirow[t]{2}{*}{ Age. } & Mean \pm SD & $52.06 \pm 12.68$ & $54.17 \pm 9.85$ & \multirow[t]{2}{*}{$0.779 \bullet$} & \multirow[t]{2}{*}{0.438} & \multirow[t]{2}{*}{ NS } \\
\hline & Range & $28-77$ & $35-70$ & & & \\
\hline \multirow[t]{2}{*}{ Sex } & Males & $34[68.0 \%]$ & $17[56.7 \%]$ & \multirow[t]{2}{*}{$1.042^{\star}$} & \multirow[t]{2}{*}{0.307} & \multirow[t]{2}{*}{ NS } \\
\hline & Female & $16[32.0 \%]$ & $13[43.3 . \%]$ & & & \\
\hline \multirow{7}{*}{ The underlying kidney disease } & \multicolumn{2}{|c|}{ Hypertension } & 31 & & \multicolumn{2}{|l|}{$62.0 \%$} \\
\hline & \multicolumn{2}{|c|}{ Diabetic nephropathy } & 11 & \multicolumn{3}{|c|}{$22.0 \%$} \\
\hline & \multicolumn{2}{|c|}{ Unknown etiology } & 4 & \multicolumn{3}{|c|}{$8.0 \%$} \\
\hline & \multicolumn{2}{|c|}{ Polycystic kidney disease } & 1 & \multicolumn{3}{|c|}{$2.0 \%$} \\
\hline & \multicolumn{2}{|c|}{ Amyloidosis } & 1 & \multicolumn{3}{|c|}{$2.0 \%$} \\
\hline & \multicolumn{2}{|c|}{ Lupus nephritis } & 1 & \multirow{2}{*}{\multicolumn{3}{|c|}{$2.0 \%$}} \\
\hline & \multicolumn{2}{|c|}{ Analgesic nephropathy } & 1 & \multicolumn{2}{|r|}{$2.0 \%$} & \\
\hline
\end{tabular}

Carotid intimal thickness/mm

0.83

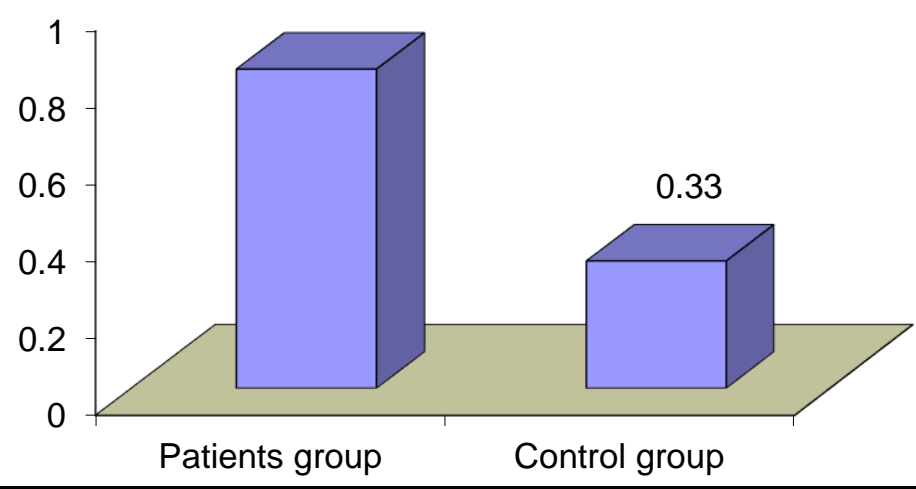

Figure [1]: Comparison between patients and control group as regard carotid intimal media thickness 
Table [2] Echocardiographic finding in the patient group

\begin{tabular}{|l|c|c|}
\hline \multirow{2}{*}{ Echocardiographic finding } & \multicolumn{2}{|c|}{ Patients group [N=50] } \\
\cline { 2 - 3 } & No. & $24.0 \%$ \\
\hline Normal echo & 12 & $46.0 \%$ \\
\hline Calcific aortic valve & 23 & $24.0 \%$ \\
\hline Calcific mitral valve & 12 & $6.0 \%$ \\
\hline Calcific aortic and mitral valve & 3 & \\
\hline
\end{tabular}

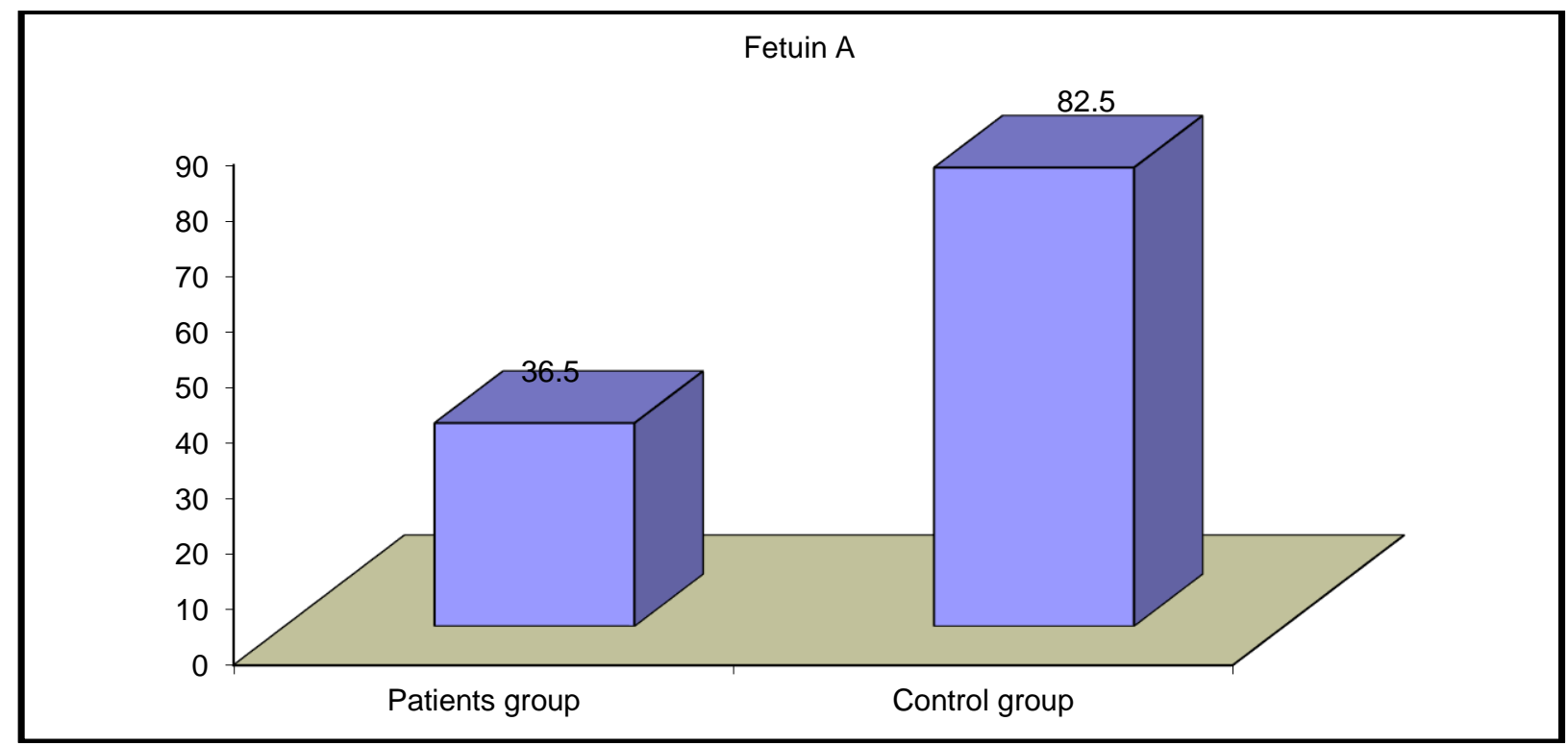

Figure [2]: Comparison between patients and control group as regard fetuin $\mathrm{A}$

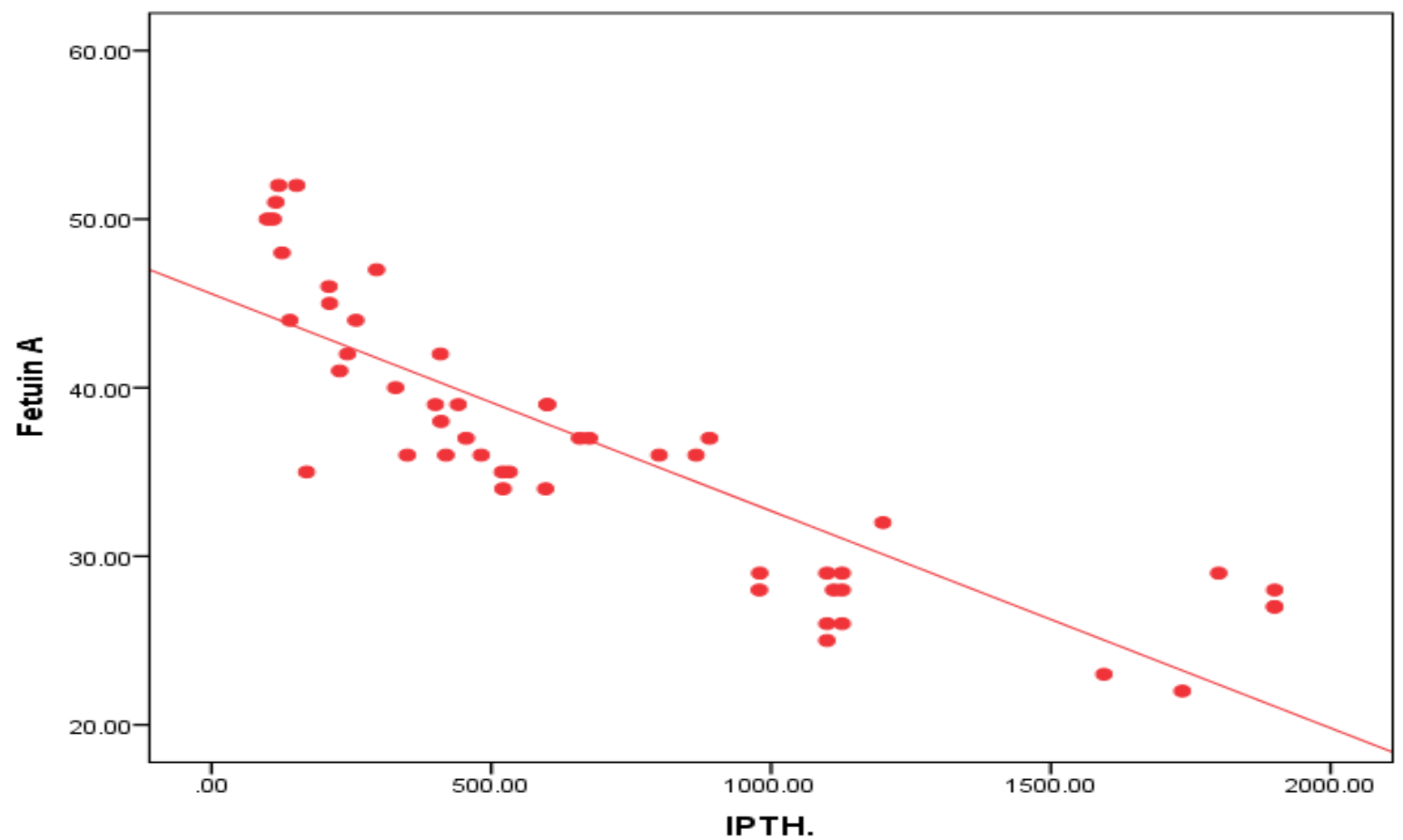

Figure [3]: Correlation between serum fetuin-A and iPTH of the patient group. [iPTH: intact parathormone hormone]. 
Table [3]: Relation between serum fetuin- $A$ and echocardiographic finding of patients group:

\begin{tabular}{|c|c|c|c|c|c|c|}
\hline & \multicolumn{2}{|c|}{ Fetuin A } & \multirow{2}{*}{ Test value } & \multirow[b]{2}{*}{ P-value } & \multirow[b]{2}{*}{ Sig. } \\
\hline & & Mean \pm SD & Range & & & \\
\hline Echo & $\begin{array}{l}\text { Normal echo } \\
\text { Calcific aortic valve } \\
\text { Calcific mitral valve } \\
\text { Calcific aortic and mitral valve }\end{array}$ & $\begin{array}{l}38.17 \pm 5.59 \\
34.78 \pm 8.14 \\
39.08 \pm 9.90 \\
32.67 \pm 5.86\end{array}$ & $\begin{array}{l}29-48 \\
22-52 \\
25-52 \\
26-37\end{array}$ & 1.172 & 0.331 & NS \\
\hline
\end{tabular}

NS: Non significant; $P \leq 0.05$ Significant

Table [4]: Distribution frequencies of Fokl polymorphism genotype among studied groups:

\begin{tabular}{|c|c|c|c|c|c|c|c|}
\hline \multirow{2}{*}{ Vit .D receptor Genotype } & \multirow{2}{*}{\multicolumn{2}{|c|}{$\begin{array}{r}\text { Patients group } \\
\text { No. }=50\end{array}$}} & \multirow{2}{*}{\multicolumn{2}{|c|}{$\begin{array}{r}\text { Control group } \\
\text { No. }=30\end{array}$}} & \multirow{2}{*}{ Test value } & \multirow{2}{*}{ P-value } & \multirow{2}{*}{ Sig. } \\
\hline & & & & & & & \\
\hline $\mathrm{Ff}$ & 0 & $0.0 \%$ & 14 & $46.7 \%$ & \multirow{3}{*}{34.489} & \multirow{3}{*}{0.001} & \multirow{3}{*}{ HS } \\
\hline $\mathrm{Ff}$ & 18 & $36.0 \%$ & 0 & $0.0 \%$ & & & \\
\hline FF & 32 & $64.0 \%$ & 16 & $53.3 \%$ & & & \\
\hline
\end{tabular}

HS: Highly significant. P $\leq 0.001$ : Highly Significant

\section{iPTH $(p g / m l)$}

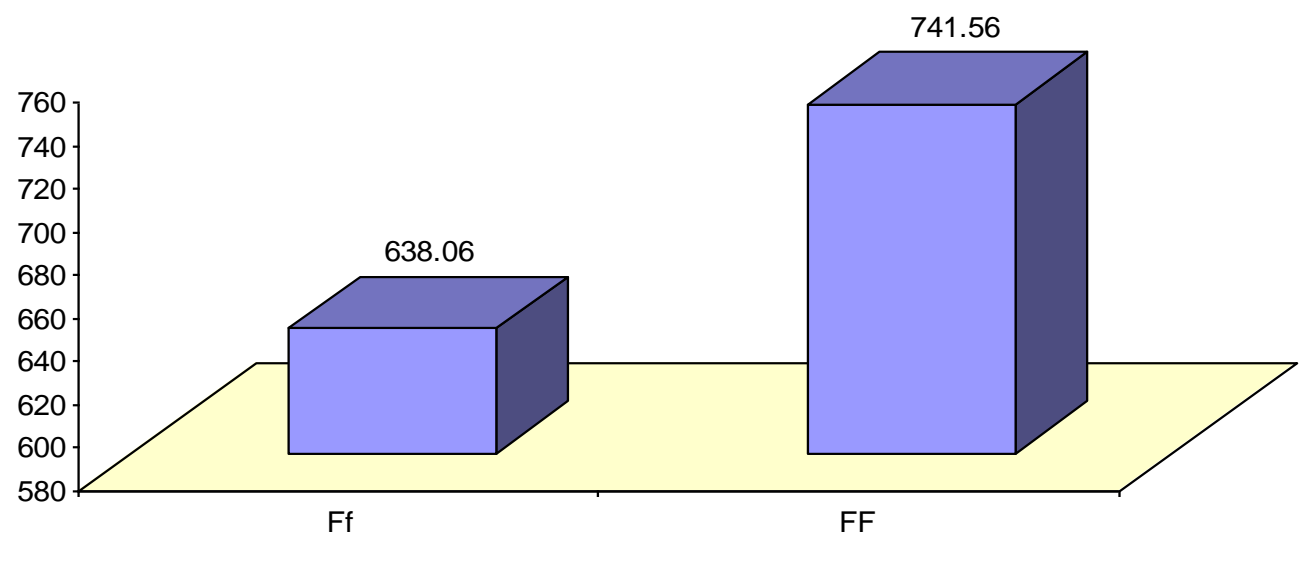

Figure [4]: Relation between Fokl polymorphism genotype frequencies and iPTH of the studied group. iPTH: intact parathormone hormone

\section{DISCUSSION}

Vascular calcification is commonly observed in patients with chronic kidney disease, and accumulating evidence indicates that its prevalence and severity correlate with long-term outcomes [10]. It was estimated that the ageadjusted cardiovascular events rate increases from 2.11 events per 100 person-years for individuals with normal GFR to 3.65 for those with CKD stage 1, to 36.60 for individuals with ESRD. Indeed, at all CKD stages, CVD mortality is disproportionately high compared to the general population. [11].
Our study detects the possible relationship between vitamin $D$ receptor gene polymorphism Fokl with fetuin-A and IPTH in Egyptian hemodialysis patients. There was no significant difference between the studied groups regarding age and sex, which means that both groups were comparable. In the current study, there was a highly significant increase in CIMT in the patient group than the control group; this agrees with the study done in Alexandria by El-Attar et al.[12], who compare 70 Egyptian patients on regular HD and 30 healthy subjects and found a significant increase in CIMT in hemodialysis patients 
compared to the control group and Paul et al.[13], who found that hemodialysis patients had significantly greater CIMT than age and sexmatched non dialyzed chronic kidney disease [CKD] patients, suggesting that hemodialysis is an independent risk factor for atherosclerosis in CKD.

In a recent study done on HD patients with and without cardiovascular disease, the authors concluded that subjects with CVD have higher CIMT than those without CVD and men had higher CIMT than women, age was the most important marker for CIMT in patients on maintenance $\mathrm{HD}[14]$.

Calcification of the aortic and mitral valves is a common finding in HD patients with a prevalence of four to five times higher than that in the general population. In a study done in Morocco on hemodialysis patients, the authors concluded that the prevalence of valvular calcification was $15 \%$ with aortic valve location and mitral valve location in $41.2 \%$, and only hemodialysis duration seems to be associated with the occurrence of calcifications and approaches the marginal level of significance ${ }^{[15]}$.

In our study, cardiac valves calcification followed aortic valve $46 \%$, the mitral valve $24 \%$, and both aortic and mitral valve $5 \%$. The difference might be attributed to many factors such as differences in the study populations, mean age and dialysis vintage, different definitions and diagnostic methods for detecting CVC, the type of phosphate binders used, and dialysate calcium concentration. In another study done by Lin and his colleagues on HD patients with a median follow-up duration was 66 months, de novo cardiac valves calcifications developed in $45.98 \%$ subjects: 58 developed aortic valve calcification alone, 42 developed calcification on mitral valve alone, and 20 developed both aortic and mitral valve calcification ${ }^{[16]}$.

Sayarlioglu et al. studied 129 patients on hemodialysis, and their results showed a $23.3 \%$ prevalence of mitral valve calcification, $21.7 \%$ of aortic valve calcification, and the overall $33.3 \%$ prevalence of valvular abnormalities [17].
In a recent Iranian study, the prevalence of mitral calcification, aortic and mitral annulus calcification, $57 \%, 54 \%$, and $55 \%$ respectively, and the overall valvular calcification was $73 \%$ is higher than the rates reported by other studies [18].

Fetuin-A is produced in the liver and acts as a strong inhibitor of calcium - phosphate deposition. It can regulate several of the key cellular events that lead to VSMC calcification, including apoptosis and phagocytosis. It interacts directly with matrix vesicle release and forms stable colloidal spheres with calcium and phosphorus, socalled "calciprotein particles" that inhibit hydroxyapatite precipitation and modulate vascular calcification processes locally and at early stages ${ }^{[19]}$.

When we compared serum fetuin A level in hemodialysis patients and the control group, we found that fetuin- $A$ is significantly decreased in patients than the control group; these in agreement with a recent study, which found serum fetuin A level was significantly decreased in HD patients while osteopontin was significantly higher in the patient group and no significant correlation was found between patients with VC and patients without VC in terms of fetuin-A, osteopontin, and 25-OH-vitamin D levels and the authors concluded that $\mathrm{VC}$ is a frequent sign in patients undergoing $H D$ and is not related to serum fetuin-A and osteopontin [20]. In contrast to our results, Herman et al., in the cross-sectional study, reported that Fetuin-A was not different between dialysis patients and healthy subjects and could not be identified as an independent predictor of aortic stiffness [24].

There was a significant negative correlation between serum fetuin-A and IPTH in the patient group; these in agreement with Amani et al.[23]. In contrast to our results, Shahnam-Valizadeh et al. found no correlation between Fetuin-A and IPTH in $\mathrm{HD}$ [21].

There was no significant correlation between valvular calcification and fetuin $A$ in hemodialysis patients in the present study. These in agreement with Ossareh etal., who concluded that, the Fetuin- 
A level was not different between patients with and without CVC and was not recognized as a predictor, while age, calcium level, and diabetes were identified as the most important predictors of calcification in their patients [18]. The Bsml and/or FokI VDR polymorphisms have been recognized as risk factors of some autoimmune diseases, including rheumatoid arthritis, Behçet's, graves' and Addison's diseases, psoriasis, multiple sclerosis, type 1 diabetes, and others. Moreover, both polymorphisms have been determined to be risk factors for colorectal, breast, prostate, and other cancers. The Fokl and Bsml polymorphisms of the vitamin $D$ receptor gene are regarded as strong markers of disturbed vitamin $D$ signaling pathway so that VDR polymorphisms could be involved in secondary hyperparathyroidism chronic renal failure [25].

In our study, the distribution frequencies of Fokl polymorphism in $\mathrm{HD}$ patients were $64 \%$ had $\mathrm{FF}$ genotype, $36 \%$ had $\mathrm{Ff}$, and $0 \%$ were ff genotype while the FF genotype was in the control group $53.3 \%$, Ff was $0 \%$, and ff were $46.7 \%$ which was highly significant. In an Egyptian study done by ElAttar et al., they found the distribution frequencies of Fokl polymorphism were FF, Ff, and $\mathrm{ff}$ genotypes inpatient group $57.1 \%, 31.4 \%$, and $11.4 \%$, respectively; while in the control group were $56.7 \%, 40 \%$, and $3.3 \%$ respectively and they concluded that there was no significant difference in the genotype distribution of Fokl polymorphism among the control group and the total patients' group [12]. In another study, the prevalence of genotypes for Fokl polymorphism was $32.6 \% \mathrm{FF}, 39.1 \% \mathrm{Ff}$, and $28.3 \% \mathrm{ff}$, in Iranian HD [21].

The difference in our and other study results could result from the influence of geographical location and ethnic differences or study sample size related to the distribution of the VDR gene polymorphisms.

There was a significant increase in $\mathrm{PTTH}$ in the patient group's FF genotype in our study. In agreement with our results, the study of Vigo et al. found that iPTH level in the FF group was significantly higher than both $\mathrm{Ff}$ and ff groups in
Spanish patients with CKD, and they suggested that Fokl polymorphisms of the VDR gene may determine the parathyroid response in CRF patients[26]. In contrast to our results, El-Attar et al. did not found a significant difference in genotype distribution of Fokl polymorphism among patients with $\mathrm{iPTH}$ less than $300 \mathrm{pg} / \mathrm{ml}$ and patients with iPTH more than $300 \mathrm{pg} / \mathrm{ml}$ [12].

In the present study, there was no significant relation between Fokl polymorphism and serum fetuin-A in HD patients; these agree with ShahnanValizadeheta|[21]

Conclusion: Vitamin D receptor gene Fokl polymorphism FF genotyping is more frequent in hemodialysis patients who have higher iPTH and lower fetuin A levels, which could identify the highrisk group susceptible to vascular calcification in hemodialysis patients and affect the management of cardiovascular events.

\section{REFERENCES}

1. Mozos I, Marginean O. Links between Vitamin D Deficiency and Cardiovascular Diseases. Biomed Res Int. 2015; 2015:109275. doi: 10. 1155/ 2015/109275.

2. Shioi A, Nishizawa Y. Vascular calcification in chronic kidney disease: pathogenesis and clinical implications. J Ren Nutr. 2009 Jan; 19 (1):78-81. doi: 10.1053/j.jn.2008.10.015.

3. Ketteler M, Westenfeld R, Schlieper G, Brandenburg V. Pathogenesis of vascular calcification in dialysis patients. Clin Exp Nephrol. 2005 Dec;9(4):265-270. doi: 10. 1007/ s10157-0050385-4.

4. Trochoutsou Al, Kloukina V, Samitas K, Xanthou G. Vitamin-D in the Immune System: Genomic and Non-Genomic Actions. Mini Rev Med Chem. 2015; 15 (11): 953-63. doi: 10.2174/1389557515666 1505 19110830.

5. Valizadeh-Shahbazloo S, Ghorbanihaghjo A, Safa J, Hallajzadeh J, Barghahi N, Mahmoodi N. Fetuin-A and vitamin $D$ receptor gene polymorphisms in hemodialysis patients J Anal Res Clin Med, 2014; 2(3): 105-11. doi: 10.5681/ jarcm. 2014.018

6. Bouillon R, Carmeliet G, Verlinden L, van Etten E, Verstuyf A, Luderer HF, Lieben L, Mathieu C, Demay M. Vitamin $D$ and human health: lessons 
from vitamin D receptor null mice. Endocr Rev. 2008 Oct; 29 (6):726-76. doi: 10.1210/er.20080004.

7. Li WH, Gu Z, Wang H, Nekrutenko A. Evolutionary analyses of the human genome. Nature. $2001 \mathrm{Feb}$ 15; 409(6822):847-9. doi: 10.1038/35057039.

8. Uitterlinden AG, Fang Y, Van Meurs JB, Pols HA, Van Leeuwen JP. Genetics and biology of vitamin D receptor poly-morphisms. Gene. 2004 Sep 1;338 (2): 143-56. doi: 10.1016/j.gene. 2004.05.014.

9. Valdivielso JM, Fernandez E. Vitamin D receptor polymorphism and disease. Clin Chim Acta. 2006; 371: 1-12. doi: 10.1016/j.cca.2006.02.016.

10. Schlieper G, Schurgers L, Brandenburg V, Reutelingsperger C, Floege J. Vascular calcification in chronic kidney disease: an update. Nephrol Dial Transplant. 2016 Jan; 31(1):31-9. doi: 10.1093/ndt/gfv111.

11. Shea MK, Booth SL. Vitamin K, Vascular Calcification, and Chronic Kidney Disease: Current Evidence and Unanswered Questions. Curr Dev Nutr. 2019 Jul 4;3 (9):nzz077. doi: 10.1093/ cdn/nzz077.

12. EL-Attar HA, Mokhtar MM, Gaber EW. Profile of vitamin D receptor polymorphism Bsm I and Fokl in end stage renal disease Egyptian patients on maintenance hemodialysis. J Clini Nephrol. 2017; 1 : 026-040. doi: 10.29328/journal.jcn.1001005

13. Paul J, Dasgupta S, Ghosh MK. Carotid artery intima media thickness as a surrogate marker of atherosclerosis in patient with chronic renal failure on hemodialysis. N Am J Med Sci. 2012 Feb;4 (2):77-80. doi: 10.4103/1947-2714.93379.

14. Kuswardhani RT, Wiradharma KG, Kandarini Y, Widiana GR, Martadiani ED. Factors associated with carotid intima-media thickness in patients on maintenance hemodialysis. Int J Gen Med. 2018; 12:1-6. doi: 10.2147/IJGM.S178276.

15. Faqih SA, Noto-Kadou-Kaza B, Abouamrane LM, Mtiou N, El Khaya S, Zamd $M$, et al. Valvular calcifications in a patient on hemodialysis in Morocco. Pan Afr Med J. 2016 Jun 2; 24:115 doi: 10.11604/ pamj. 2016.24.115.7147

16. Lin FJ, Zhang X, Huang LS, Zhou X, Ji G, Luo $\mathbf{R}$, Jiang GR, Lu W. De novo cardiac valve calcification after hemodialysis in end-stage renal disease patients predicts future cardiovascular events: A longitudinal cohort study. Cardiorenal Med. 2019; 9 [4]: 229-239. doi: 10.1159/000494701.

17. Sayarlioglu H, Acar G, Sahin M, Altunoren O,
Yavuz YC, et al. Prevalence and risk factors of valvular calcification in hemodialysis patients. Iran J Kidney Dis. 2013; 7: 129-134.

18. Ossareh S, Marghoob B, Bayat R. Relationship between Fetuin-A and vascular or valvular calcification in hemodialysis patients. J Clini Nephrol. 2019; 3: 001-011. doi: 10.29328/journal. jcn.1001021

19. Ossareh S. Vascular calcification in chronic kidney disease: mechanisms and clinical implications. Iran J Kidney Dis. 2011; 5: 285-299.

20. Ulutas O, Taskapan MC, Dogan A, Baysal $T$, Taskapan H. Vascular calcification is not related to serum fetuin-A and osteopontin levels in hemodialysis patients. Int Urol Nephrol. 2018 Jan; 50[1]:137-142. doi: 10.1007/ s11255-017-1740-6

21. Ghorbanihaghjo A, Argani H, Samadi N, Valizadeh S, Halajzadeh J, Yousefi B, Rashtchizadeh N. Relationship between vitamin D receptor gene Fokl and Apal polymorphisms and serum levels of fetuin-A, vitamin $D$, and parathyroid hormone in patients on hemodialysis. Iran J Kidney Dis. 2014 Sep;8(5):394-400. PMID: 25194407.

22. Altuntaş A, Yiğit A, Uz E, İnal S, Kidir V, Aydin B, et al. The relationship between serum fetuin a levels and fetuin gene polymorphism in hemodialysis patients. Biomed Res 2017; 28 [2]: 495-502

23. Amani KM, Amany MA, Maha AH, Nagwa AM, Solaf AK. Associations of fetuin-A level with vascular disease in hemodialysis patients with or without type II diabetes mellitus. Egyp J Internal Med. 2013; 25 [40]: 218-22. DOI: 10.4103/11107782.124996

24. Hermans MM, Brandenburg V, Ketteler $M$, Kooman JP, van der Sande FM, Gladziwa U, et al. Study on the relationship of serum fetuin-A concentration with aortic stiffness in patients on dialysis. Nephrol Dial Transplant. 2006 May;21[5]:1293-9. doi: 10. 1093/ndt/gfk045.

25. Valdivielso JM, Fernandez E. Vitamin $D$ receptor polymorphism and disease. Clin Chim Acta. 2006; 371: 1-12. doi: 10.1016/ j.cca.2006.02.016.

26. Vigo GE, Cadarso-Suárez C, Perez FR, Romero BR, Devesa MJ, Segura IC. Association between vitamin $\mathrm{D}$ receptor Fokl. Polymorphism and serum parathyroid hormone level in patients with chronic renal failure. J Endocrinol Invest. 2005 Feb; 28 [2]: 117-21. doi: 10.1007/BF03345353. 


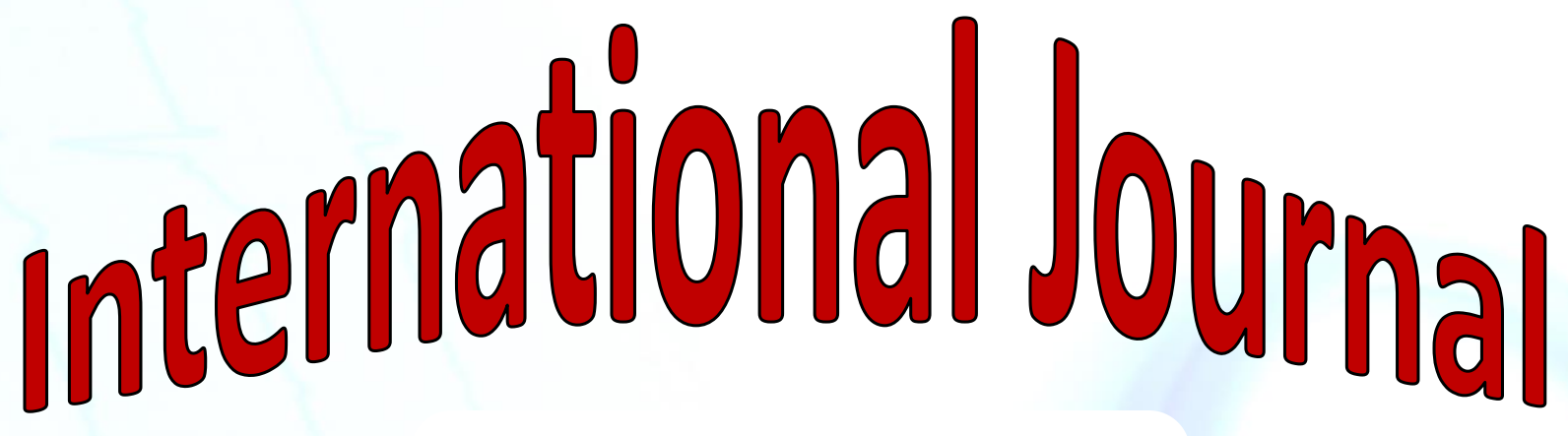

https://ijma.journals.ekb.eg/

Print ISSN: 2636-4174

Online ISSN: 2682-3780

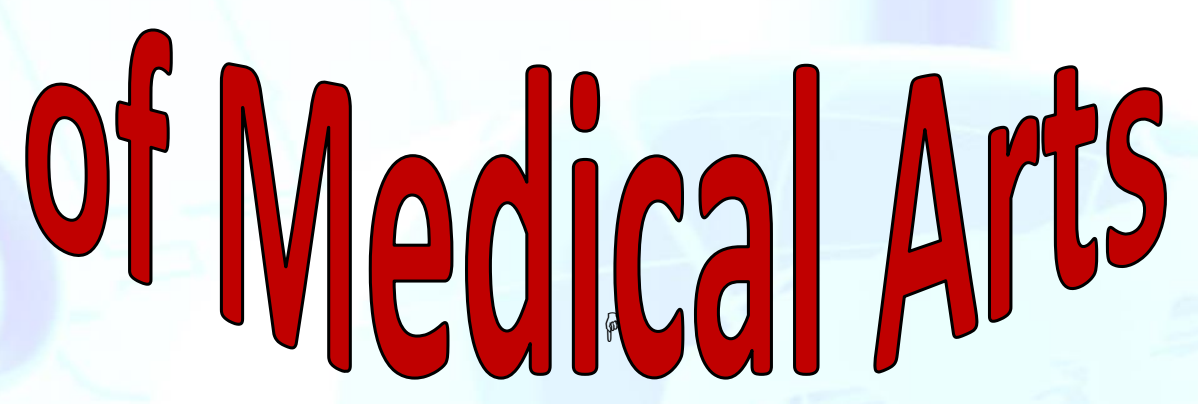

